\title{
Eclecticism and its Discontents
}

\author{
Thomas J. Farrell
}

\begin{abstract}
The widely-praised "open" eclecticism of George Kane's editions of Piers Plowman has simultaneously elicited discontent for its inattention to textual history, its susceptibility to misuse, and its conflicting conceptions of poetry. These evolving attitudes reveal how the impressive methodological rigor that gives Kane's system strength problematically clashes with the subjective editorial judgment it proclaims as essential. Eclectic editors's insistence that a textually straightforward Chaucerian line - Canterbury Tales III 838 - be emended either conjecturally or from a late and isolated textual tradition highlights that problem; the accuracy with which several indisputably brilliant Chaucerian lines are preserved in the witnesses warns us to be wary of eclectic overreach.
\end{abstract}

\begin{abstract}
A
SPECIES OF SCHIZOPHRENIA HAS COME TO CHARACTERIZE ATTItudes towards the eclectic method of "deep" or "open" editing pioneered by George Kane and employed by Kane and his collaborators in the Athlone editions of the A Version, the B Version, and the C Version of Piers Plowman. Even in the midst of evident and strong admiration, that methodology has generated a persistent resistance. Thus the same critic who can begin a retrospective evaluation by judging that "George Kane remains, and will remain, the greatest editorial mind — and the greatest scholar of texts - who has ever engaged with Middle English" can, a few pages later, register a fairly serious discontent:
\end{abstract}

His 'open analysis' of the variants cordons off the text from the history that has produced the evidence for it. It isolates the individual instance and flattens the variant-evidence into a single temporal plane. All readings, whatever their antiquity, are equally present and potentially equal in evidentiary value. (HanNa 2010, 1, 7)

Hanna's reaction is not an isolated phenomenon. Without dislodging - and often without wanting to dislodge-eclecticism from its current pre-eminent position, a series of critics has slowly but progressively articulated a 
core of dissatisfaction that has identified irreducible limitations in Kane's eclecticism, ways in which it inherently creates and ultimately enshrines the excesses that must bedevil it.

One useful taxonomy distinguishes between "positivist" editors and theorists, who believe that the documentary evidence in the manuscripts must be an editor's primary, perhaps only, resource, and "rationalist" approaches (like Kane's) in which that evidence is conceived as the raw material to be processed-more or less depending on its quality - by the editor (Sснмidt 2011, vol. 2, 13-17). In extreme cases, positivists have been willing to consider Kane's careful logic equivalent to the practice of discredited rationalist editions like Richard Bentley's 1732 Paradise Lost, but even a cursory study of Kane's work reveals how much it differs from "the eighteenth-century style of interventionist eclecticism and the Bentleyan guides of a single person's own 'learning, taste, and judgment" (RAMSEY 2010, 179). Kane began precisely by attending with more care than any of his predecessors to the lessons of his large-scale transcription of the manuscripts of Piers Plowman A. In that process he catalogued the scope and variety of scribal error; at its conclusion, he classified that error into the manifold but largely predictable forms that constitute what he called the usus scribendi of those who copied medieval texts. Kane and E. Talbot Donaldson later characterized the tendency of that usus "to flat statement or crude overemphasis, diffuseness in denotation and loss of connotation, dilution of meaning and absence of tension, in general a bald, colourless and prosy expression" (KANE-DonALDsOn 1975, 130).

In the most important sense, then, the documentary evidence does constitute Kane's "primary" - first - resource: his rationalist distrust of manuscript lections is rooted in intense study of the manuscripts. ${ }^{1}$ Because scribes so often made the same copying errors or deliberate changes in the same textual situations, Kane argues, an editor often cannot confidently attribute the existence of shared variants to a genetic relationship between different witnesses: the likelihood that such agreement had occurred coincidently in unrelated manuscripts is too great. And with genetic evidence dismissed, Kane concludes that "The sole source of [textual] authority is the variants themselves, and among them, authority, that is originality, will probably be determined most often by identification of the variant

1. A. S. G. Edwards makes what I take to be a similar point: "if 'learning, taste and judgment' are to be the 'last' resort of the editor, what is to be the first?" (EDwards 2010, 337) 
likeliest to have given rise to the others" (KANE 1988, 115). But that theory works best when the scribal usus can consistently be distinguished from what Kane and Donaldson define as the "vigorous, nervous, flexible and relatively compressed [style of the poet], made distinctive by characteristic mannerisms and figures" (KANE-DonaLDson 1975, 130). Slightly altering Kane's terminology for clarity, I will call the sum of those effects the usus poetandi. When the eclectic editor identifies the vivid qualities of the usus poetandi in "the variant likeliest to have given rise to the others", and the degraded usus scribendi in the rejected variants, deep editing has achieved its apogee.

Unsurprisingly, however, that kind of discrimination has not always won unanimous agreement, especially when a conjectural emendation-a variant not present in the manuscript record - is cited as as the one "likeliest to have given rise to" those that do appear, as in this famous - or infamous - example from the B Version:

"I shal cessen of my sowyng", quod Piers, "\& swynke no3t so harde,

Ne aboute my [bilyue] so bisy be na moore" (VII, 122-23)

All B manuscripts read "bely ioye" in line 123; the lection "bilyue" appears only in two A witnesses, although its sense is supported by the non-alliterating synonym "liflode" in all other A witnesses (KANE 1988, 357). ${ }^{2}$ Kane chooses the minority variant for the A Version because, in addition to providing a required alliterating stave, "bilyue" is a "harder" reading that fifteenth-century scribes would have been unlikely to introduce (KANE $1988,450)$. In the B Version, with alliteration no longer an issue, the same logic — rejection of "bely ioye" as the "easier" lection — is the rationale for the conjectural emendation (KANE-Donaldson 1975, 85-86)33; eclecticism further minimizes the significance of unanimous manuscript support for "bely ioye" by arguing that a single scribal substitution of that lectio facilior in the B archetype would sufficiently explain it (HANNA 2014, 41). But by the same logic, a demurrer might argue, the archetypal B reading is explained equally well by a single substitution of "bely ioye" for "bilyue" in the archetype by Langland, a poet who (the argument goes) had recog-

2. Large-scale revisions to the $C$ Version eliminated the line from that work.

3. Like all students of the Athlone editorial processes, I am deeply grateful to BARNEY 1993, which allows us to find the justification for a single lection without re-reading the entire edition. 
nized not only the lexical obscurity of "bilyue" for his audience (evidenced by the widespread substitution of "liflode" in A), but the possibility that some of them might read "bileue", thus disastrously suggesting that Piers was renouncing serious thought about his Creed (Hudson 1977, 44). As a result, even critics sympathetic to eclectic processes, including Schmidt in his edition, have rejected the conjectural emendation of the $B$ Version to "bilyue".

Nevertheless, that kind of discontent remains a wholly local argument about the application of Kane's logic to one crux. Such local critiques leave Kane's eclectic methodology untouched, because its central principle stands: recognizable scribal or metrical deficiencies may vitiate better-attested lections, rendering a poorly attested variant or a conjectural emendation the correct editorial choice.

As a system, this edition validates each individual reading in terms of every other reading, which means that if some of the readings are correct, then - unless the editorial principles have in an individual instance been misapplied - they must all be correct (Patterson 1987, 92).

The emendation to "bilyue" looks like a "misapplication": since Kane accepts "bely ioye" as an authorial reading in A VIII: 112, and KaneDonaldson emends to "bely ioye" in the parallel B Version passage (B VII: 130), the designation of "bely ioye" as usus scribendi at B VII, 123 appears somewhat willful. But such local flaws cannot sustain discontent with the method qua method.

Patterson, however, found his own form of discontent: although an eloquent defender of Kane and Donaldson's method, he discovered within eclecticism an editorial conflict of interest: an inconsistency, a hesitation between two competing concepts of poetry.

The conflict, then, between the more appropriate and the more diffcult reading is not simply between two criteria of textual originality but between two ways of editing and two views of poetry. The first is rhetorical and empirical; it assumes that literature is a means of conveying truth and that that truth can be apprehended by the same methods as are applied to other cultural objects. The second is symbolist and intuitional; it assumes that literature is a special kind of linguistic object that proceeds from mysterious sources (in the past designated as Genius, but more recently called Language) and that offers meanings that can be understood only by special faculties. (PAtterson 1987, 96) 
Nevertheless, Patterson, who was not an editor, identifies no textual cruxes created by the problem he has identified. ${ }^{4}$ Nor could he, at least readily: in one sense, discontent with Kane's eclecticism can never depend on its failure to choose between the "rhetorical mandate" and the "way of genius", because eclecticism, it can be shown, has always already chosen the latter.

Editorial theory today responds to diverse impulses. In recent years, historicist reading practices - ironically, the sort of reading favored by Patterson - have justified a resurgent interest in single-text editions that can be said to reproduce (to some extent) real historical readings of the text. ${ }^{5}$ That project, rooted in a disinterested appreciation of the history of reception of Piers Plowman or the Canterbury Tales, remains a central concern of humanistic and literary study. But our discipline has always complemented such "appreciation" with both philology's "skeptical critique" of textual history and an "enthusiastic engagement" with great poets like Langland and Chaucer (Kelly, Simpson, et al. 2013, 16-17), and both of those traditions silently reinforce the determination of eclectic editors to trace textual history in detail, to recapture the "definitive form" of a unique textual

4. In arguing that critiques of the Athlone text "could only be effective if they were part of a sustained effort to provide a contrary hypothesis by which to explain the phenomena" (1987, 92), Patterson endorses the B Version's famous challenge to other editors (Kane-Donaldson 1975, 220). But he nowhere shows any awareness of A. V. C. Schmidt's efforts to revisit their theory and practice, already advanced as he wrote, even if Schmidt's hypothesis might better be understood as "alternative" than "contrary".

5. The argument that Caxton's edition "was the basis for all versions of Malory in circulation" until Vinaver's edition of the Winchester MS in 1947 relies on this model implicitly but unmistakably. (SPISAK 1983, 605). More recently, a very conservative edition of the Ellesmere MS (San Marino, CA Huntington Library MS Ellesmere 26 C9) has become a popular form for reading and teaching the Canterbury Tales (Boenig And TAylor: 2012), and a new edition of the Piers Plowman A Version based on Oxford, Bodleian MS Rawl. poet. 137 argues unapologetically that that manuscript "deserves attention for itself and for what it can tell us about the transmission of an influential document of fourteenth-century English literary and intellectual culture" (VAUGHAN 2011, 40-41). A similar concern with medieval reading informs interest in the ways readers eked out their texts (Bowers 1992). Finally, readily-available digital versions of manuscripts of Chaucer, Langland, and Margery Kempe manifest the same trend, underscored by the selection for the first volume of the Piers Plowman Electronic Archive of the notoriously idiosyncratic MS "F" (AdAms, et al. 2000). The complexities of these theoretical developments are only now being explored (RoBinson 2013). 
experience painstakingly created by an author of genius (WATson and JENKINS 2006, 27-31). At least in the case of some authors, that is, an editor may legitimately define the task at hand as the recreation of a verbal structure whose only previous existence in precisely that form occurred in the author's mind (TANSELLE 1989, 40-41).

I cannot claim to have a comprehensive knowledge of all editing in Middle English over the last couple of generations. But with the exception of the Pearl-Poet, whose works, extant only in a single manuscript, cannot be edited eclectically, all of the recognized textual geniuses writing in Middle English have been the recipients of an eclectic edition in that time frame, and each of those editions cites the author's genius as a substantial rationale for the chosen editorial method: the quality of the author's usus poetandi simultaneously requires and justifies an eclectic methodology to recover the ipsissima verba of the author-genius. In addition to the Athlone Piers, we have editions of Chaucer by Donaldson and Jill Mann, the Watson-Jenkins edition of Julian of Norwich, and most recently, A. V. C. Schmidt's parallel-text of four versions of Piers. ${ }^{6}$ In stark contrast, other poets, writing at a lower altitude, are not eligible for eclectic editing. "No threat of a critical edition hangs over the Confessio", writes Derek Pearsall $(1985,98)$, prophetically discerning the best-text principles that would later inform our only recent edition of John Gower's English poem (Gower 2006). Kane himself, while insisting that "I have yet to come upon an instance of [scribal improvements of the text] in the case of a great work", adds the concession that "A scribe copying Lydgate might well seem to soar by variation" from the original $(1986,293)$. In uninspired poetry, the usus poetandi inevitably merges with the usus scribendi, disabling the practice of open editing. The essential, the constitutive role of genius in any eclectic editorial project could not be clearer.

For that reason, there have been few objections to cruxes in which Kane and his collaborators print what Patterson would call the rhetorically appropriate lection. The process of choosing readings that make sense, that maintain what Patterson calls the "consistency" of the text $(1987,95)$ and that Kane and Donaldson call "its whole structure of meaning" $(1975,131)$ generally runs smooth; only for for the more admittedly difficult process of

6. While Pearsall criticizes Schmidt's editorial conservatism (see below), Schmidt's persistently-argued principle that "parallel editing is the most satisfactory way to produce a truly critical text" (2011, vol. 2,81$)$ actually extends the Kanian principle of considering "all variants". 
discerning the usus poetandi need the editors challenge users to evaluate their editorial system by "reenacting it" (KANE-Donaldson 1975, 220). That invitation suggests that persistent discontent with their system may better be explored by considering the parallel work of another editor. Over more than forty years, Pearsall's own engagement with Piers Plowman, and specifically with the C-Text, has embodied multiform responses to the principles and practice of eclectic editing. Beginning from a conviction that the C-Text had been badly represented and consequently underappreciated for more than a century because of Skeat's poorly-chosen base manuscript, Pearsall published in 1979 a complete text of that poem. ${ }^{7}$ Although he consulted three other manuscripts, that work was unabashedly a best-text edition of San Marino, Huntington Library MS HM 143 (sigil X): "no attempt has been made to reconstruct the author's original from which $\mathrm{XU}$ are derived" (Pearsall 1979, 22). Nor was his choice of method merely pragmatic: at about the same time, Pearsall explicitly rejected the theoretical underpinnings of Kane's eclectic system.

The idea of a definitive textual moment, a moment toward which the imagination strains amid much creative grumbling, and away from which it sinks as inspiration declines, ... has no better warrant as an a priori hypothesis, and conforms no better to the evidence, than the alternative view of Langland's poem as existing in a state of continuous evolution, of which we glimpse certain stages, more-or-less arbitrary in themselves, in the extant manuscripts. $(1985,100)$.

The subtlety of this argument is pointed by its historical moment: ten years after Kane-Donaldson had constructed the B Version by means of their ability to discern Langland's usus poetandi, the specific linguistic form of his genius, Pearsall interrogates the ontological questions posed by the existence of $\mathrm{C}$, supporting his chosen best-text methodology with the prospective argument that $\mathrm{C}$ cannot be edited on the same eclectic basis used to produce the Athlone $A$ and $B$ Versions. While the same Langlandian genius that produced $\mathrm{A}$, with all of its unresolved questions, might arguably later have produced resolutions for those difficulties in $B$, there is in that schema little room for C. Langland's evident inability to accept the B Version as final must have arisen from one of two causes. If his genius had

7. The 1979 edition builds on Salter and Pearsall 1967, which prints substantial excerpts. 
declined, the $C$ Version becomes ineligible for editing on the same terms as $\mathrm{B}$; but if $\mathrm{C}$ is the product of a different form of genius, one that necessarily reduces the term "Langland" to a functional cipher (Foucault 1969), then the specific identify of that poetic genius proves ephemeral, and the logic of using $\mathrm{C}$ as a guide to the readings of $\mathrm{B}$ - or vice vers $\mathrm{C}$ - cannot be justified. ${ }^{8}$

However, the subtlety of that critique has generally been lost amid the thunder of Pearsall's more direct broadside at the subjectivity of Kane-Donaldson:

An intelligent contemporary editor, with an intimate knowledge of his poet's language and idiom, may hit upon readings that seem preferable, not only to him and his modern counterpart, but that might even have been preferred by the poet himself if he had thought of them. $(1985,95)$

More substantively, Pearsall questions not so much the assumption that Langland generated poetry "of a different kind from that of lesser versifiers, having the capacity of an achieved and incomparable fullness of meaning", but the reliance on such notions while editing: "such assertions about the nature of the poetic process are acts of faith and are thus distinct from the acts of literary judgment that alone are integral to editorship" $(1985,101)$.

Two published responses intervened between that essay and Pearsall's "New" edition of the C-text in 2008. The first was Kane's direct counterstatement, which rejects Pearsall's methodological critique on its own terms:

I am at a loss to understand what 'the acts of literary judgment' in that stricture were thought to be, but the expression seems to suggest a notion that the excellence of a literary work is somehow detachable from its language, as if style, and form, and meaning did not exist in and by virtue of the physical features of a text, its language.. The distinctiveness of the style of a great poet and the possibility of characterizing it are a main premise of textual criticism. (KANE 1986, 210-11)

For Pearsall especially, perhaps, this appeal to verbal style and form-in effect, to the genius embodied by the text - laid an effective foundation

8. Schmidt agrees that $\mathrm{C}$ is "less a revision of $\mathrm{B}$ than a fresh 'version' of the poem that began at the beginning, where the writer immediately introduced striking new material" (2011, vol 2, 53). 
for the 1997 publication of the Athlone C Version, edited by George Russell and Kane, whose response to the manifold challenges of editing $\mathrm{C}$ clearly overturned some of Pearsall's thinking. His "New Annotated Edition of the C-Text", published in 2008, presents a substantial and significant methodological alteration of the 1979 edition.

We should not be misled by the suggestion that the later edition is "predicated upon a single copy" (HaNna 2014, 34), which, in context, simply reminds us that any edition of Piers will necessarily reduce the complexity present in its textual tradition. When considered in detail, the evidence is strong that by 2008 Pearsall has largely been converted to a species of editorial "rationalism". Using Passus 8 as a random sample, we may count 24 emendations of X in the explicitly best-text edition of 1979, of which about ten correct in very simple ways "obvious mechanical errors [or] readings ... neither linguistically nor contextually likely" (Pearsall, ed. 2008, 379). Twenty-one of those twenty-four emendations return unchanged in 2008; in the other three cruxes the new edition has altered the copy-text more substantively. But there are in addition twenty-one new emended readings, most based on "the corpus of variants in R[ussell-]K[ane] and . . the emendations proposed by R[ussell-]K[ane] and Sch[midt]" (2008, 17-18; 385). By adding a new, substantive emendation to his text more than once in every fifteen lines, Pearsall has certainly moved much closer to Kane's method, even while seeking to practice it more discriminatingly. We should therefore not be surprised that he later declined to endorse Schmidt's "keen attachment to the copy-text" $(2010,30$ n25), because he finds that "In substantive emendation [Russell and Kane] are always persuasive, if not always compelling, and there are some brilliant major emendations with far-reaching implications for the the interpretation of the text" (2010, 29). Only in the context of those remarks can we properly appreciate the remaining criticisms of what he sees as excesses in the Russell-Kane C Version: his complaints about their belief in a narrow set of Langlandian rules for meter, rhetoric, grammar, and formal register should not be taken as "an argument for best text-editing, which demonstrably has many defects, but for a more base-text-friendly interventionism, something more akin to the moderate editorial course pursued by Schmidt" (2010, 34).

Thus Pearsall, although clearly no longer content with best-text editorial strategies, declines to articulate a committed editorial philosophy. $\mathrm{He}$ is wowed by what eclecticism can accomplish, but he has not been wholly won over. He does not explain how an editor might practice the desired, "more base-text-friendly interventionism" without falling into the "keen attachment" to that base-text and the inappropriately timid intervention- 
ism it spawns. ${ }^{9}$ Pearsall clearly admires the eclecticism of Russell-Kane, and makes substantial use of its results; nevertheless, and despite its role in producing those "brilliant major emendations", he remains unwilling to trust Russell-Kane's sense of the Langlandian usus poetandi, and certainly unwilling to believe that Langland consistently adhered to its strictures (2010, 31-34). Pearsall still wants all the benefits of eclectic methodology; but his practice bespeaks a discontent originating in a conviction that those benefits cannot be achieved without excess.

This conundrum - the discontent that will not go, and cannot be argued away — can be further illustrated, confirmed, and extended by analysis of a line from the Wife of Bath's Prologue, one that actually presents almost no editorial difficulties, but has nevertheless long proven irresistible to eclectic editors. When the Friar laughs at the Wife's "long preamble of a tale", the Summoner opens a quarrel that will last the rest of Fragment III:

"Lo," quod the somonour, "Goddes armes two!

A frere wol entremette hym everemo.

Lo, goode men, a flye and eek a frere

Wol falle in every dyssh and eek mateere.

What spekestow of preambulacioun?

What! amble, or trotte, or pees, or go sit doun!” (III, 833-38) ${ }^{10}$

The collation to line 838 reveals the seven major versions of this line (WIFE OF BATH 1996). I have italicized the major variants:

0 What amble or trotte or pees or go sit doun

1 What amble or trotte / be pes and go sit doun
$\mathrm{Ad}^{3} \mathrm{Bo}^{1} \mathrm{Bo}^{2} \mathrm{Ch} \mathrm{Cp}$ Dd El Fi Gg $\mathrm{Gl} \mathrm{Ha}{ }^{2} \mathrm{Ha}^{4} \mathrm{Ha}^{5} \mathrm{Hg} \mathrm{Hk} \mathrm{La} \mathrm{Lc} \mathrm{Mc}$ $\mathrm{Mg} \mathrm{Ph}^{2} \mathrm{Ph}^{3} \mathrm{Pw} \mathrm{Ra}^{2} \mathrm{Ra}^{3} \mathrm{Ry}^{1} \mathrm{Si} \mathrm{Sl}{ }^{1}$ $\mathrm{Sl}^{2} \mathrm{Tc}^{1} \mathrm{To}^{1} ;$ amble] a. pu Gl; or pees] o pes $\mathrm{Si}$; doun] a doun $\mathrm{Ha}^{2} \mathrm{Hk} \mathrm{La}$ $\mathrm{Mc} \mathrm{Ra}^{2} \mathrm{Ra}^{3} \mathrm{Sl}^{1} \mathrm{To}^{1}$

$\mathrm{Ad}^{1} \mathrm{En}^{3} ;$ doun] a doun $\mathrm{En}^{3}$

9. In this context we may be reminded of Donaldson's unfortunate comparison of the editor to a man choosing a series of wives (1966, 103-04).

10. Quotations from Chaucer's Canterbury Tales cite RIVERSIDE 1987 by Fragment and line number. 
2 What amble / or trot / or pees / or $\mathrm{Ht} \mathrm{Ld}^{1} \mathrm{Ln}$; or pees] either p. $\mathrm{Ld}^{1}$ sit $a$ down

3 What amble or trotte or go sitte a $\mathrm{Mm}$ doun

4 What amble or trotte or pisse or go sitt doun

$\mathrm{Ds}^{1} \mathrm{Cn}$ En ${ }^{1}$ He Ii Ma Ps Py Se; trotte or] trotte Sir Ii; doun] a doun Cn He Ii Ma Py

5 What ambil or trot or pis or sit a N1 down

6 What ambyl or trot go pysse or syt a doun

$\mathrm{Cx}^{1} \mathrm{Cx}^{2} \mathrm{Ld}^{2} \mathrm{Ne}$ Pn Tc ${ }^{2} \mathrm{Wy} ; a$ doun] doun $\mathrm{Ld}^{2}$

Two elements create most of the variants: alternation between the lections "pees" and "pisse", and the placement of the word "go". Since none of the extant witnesses can be understood to include the verb pesen, whose imperative or subjunctive form would necessarily be peese or pese (with inflectional -e) we may accept the verdict that "The noun pees in a place requiring a verb is highly suspicious" (Donaldson 1976, 106). Discontent with that noun generated a verb governing "pees" in Ad1 En3 (variant 1); surely the same dissatisfaction (if not mere absent-mindedness) caused the scribe of $\mathrm{Mm}$ to omit the word (variant 3). Nevertheless, given that collation, "pees" is almost certainly the correct reading. All of the other variants are easily derivable from it through well-attested scribal practice. To create an argument for "pisse", one would necessarily explain the shift of so many witnesses away from that form as a species of bowdlerization or self-censorship; but there is no evidence of scribal squeamishness about the word "pisse" some 100 lines earlier, when all fifty-five witnesses to "How Xantippa cast pisse upon his heed", or (before that) when all fifty-six witnesses to whether "myn housbonde pissed on a wal" preserve those original readings (III, 729, 534; Wife of Bath 1996, 703, 534). ${ }^{11}$ The sheer number of witnesses reading "pees" may not be persuasive, especially to an eclectic editor, but Hanna's call for attention to "the history that has produced the evidence" requires us (if not Kane) to consider the quality and distribution of the witnesses supporting that lection: in the terms employed by

11. Similarly, "Nicholas was risen for to pisse" appears in every legible witness to the Miller's Tale (I, 3798; Miller's TALE 2004, 610). This evidence trumps Riverside's argument that "scribes seem more often to reduce obscenity than to introduce it" (1126), which cites only one reading from Cp in the ThopasMelibee link. 
the Canterbury Tales Project, almost all of the unrelated but authoritative "o" witnesses - including all of the very best manuscripts: $\mathrm{El}, \mathrm{Hg}, \mathrm{Ch}, \mathrm{Dd}$, Bo2 - and genetic groups $c, d$, e read "pees", while the only recorded alternative is confined to two related groups, $a$ and $b$, and a few miscellaneous witnesses (Robinson 1997, 79-81). Moreover, about half of the witnesses with "pisse", mostly those from group $b$, contain the additional shift of "go" to the middle of the line. "What! ambyl or trot; go pysse or syt a doun" is an attractive line, but its position among the other variants clearly labels it a scribal improvement on the earlier scribal form found mostly in group $a$. Thus the base form of the line with "pees" not only appears unanimously in all the earliest and best manuscripts, but is also the most likely source of the variants that do exist, and is the durior lectio for which puzzled scribes have sought a facilior alternative.

Nevertheless, eclectic editors have been remarkably unwilling to not emend that well-attested line. Mann cites the earlier emendation to "pace" suggested by Koch and noted by Manly-Rickert, but insists that the word have a specifically equestrian sense: a "distinctive lateral gait, in which the fore and hind legs on one side move in unison" (OED pace, n.1, 6.b); she notes, however, that the equine sense of that word "is not recorded elsewhere as a verb at this date" (MANN 2005, 898). In her logic, both pees and the ordinary sense of passe, meaning "walk", fail to develop sufficiently the horsey metaphor of "Amble or trotte", and therefore reek of the "prosy utterance" of the usus scribendi. But her preferred lection-paas-cannot pass muster: the OED cites no such usage before 1595, and while the form Mann prints might provide an orthographic explanation for a scribal shift to pees, it too lacks the inflectional -e needed in any plausible verb. Everything we know of Chaucer's language argues against paas. Donaldson plumps for the group a reading (DonALDson 1975, 217), even though it is absent from Dd, usually the best $a$ witness; his fellow card-carrying eclecticist, Ralph Hanna $(1997,226)$, suggests in a textual note that the minority manuscripts and Donaldson read "pisse ... . probably correctly". Perhaps, then, the fact that "pees" still stands in the Riverside Chaucer's text (RIVERSIDE 1987, 1126) constitutes a tacit recognition of the countervailing weight of those early, authoritative witnesses reading "pees", and the logic that makes "pees" both the lectio durior and the likely source of the existing variation. Donaldson eventually acknowledges those difficulties explicitly, finally emphasizing the value of making readers aware of the minority lection; as editor he wants to be sure that "pisse" is "as it were, thrown in their faces" (Donaldson 1976, 107): the editor as Xantippe. 
I am willing to grant that we are all better off for having thought more carefully about III, 838 and its various possibilities of meaning. But eclecticism's determined intention to wreak emendation on that very straightforward line deserves at least as much attention. It is just too easy to detail objections to the manifestation of usus poetandi assumed by each emendation. Since the fourth term of Summoner's comment cannot be made to fit an equestrian metaphor (we might ask Mann), why must the third? Mightn't the genius of Chaucer be sufficiently preserved by a line balanced between a Friar imagined first as a horse and then as a solidly human avatar of the willfulness horses were conventionally used to represent? And there are similar objections to Donaldson's quick characterization of "the speaker's anal personality": how does the Summoner demonstrate the "excessive orderliness, parsimony, or obstinacy" (OED, anal, adj. and n.; special uses 3) implied by that claim? Both in parrying the Friar's claim to be out of the Summoner's jurisdiction - "so been wommen of the styves" (III, 1332) — and in not rising to his bait - "lat hym seye to me / What so hym list; whan it comth to my lot, / By God I shal hym quiten every grot" (III, 1290-92) - the Summoner might be thought to act with whimsical misdirection and genial restraint. The obsessive desire for an immediate, tit-for-tat assault on the Friar, implicit in Donaldson's emendation, is hardly an inevitable reading of his character.

The scribal genius (if I may be permitted such a term) who originated group $b$ 's witty line bespeaks a more musical sort of poet; oddly enough — or not - each genius might be thought akin to the genius in that editor's mind: that familiar discontent with the subjective nature of eclectic editing rising again. But Kane and Donaldson have addressed that objection:

[W]e admit to subjectivity, but is seems to us that editorial subjectivity, correctly understood in the circumstances of this text, is not merely an inevitable factor but a valuable instrument. The data are abundant; the editor's subconscious mind cannot fail to store so many impressions from comparison between readings strongly presumed original and readings evidently or almost certainly scribal that he will at length acquire, as we hope we may have done, some accuracy of feeling for the turns of speech and even of thought respectively characteristic of the poet and his scribes. (Kane-Donaldson 1975, 213; cf. Kane 1966)

This argument cannot be rejected out of hand. Just as Kane is beyond question one of our great readers of Langland, so Donaldson and Mann, cer- 
tainly among our greatest readers of Chaucer, have a fair claim to expertise in Chaucer's poetic genius. But their disagreement - or more precisely the fact that their agreement extends no further than an insistence on some form of emendation, conjectural or otherwise - requires a certain level of discontent with the editorial value of their subjectivity, which, having first created the crux, has evidently remained unable to resolve it.

The fact that there is little reason outside of what Patterson called "the way of genius" to question the manuscripts in III, 838 thus suggests that we might attend a bit more carefully to the ontology and preservation of poetic genius in texts. Canterbury Tales III, 838 usefully directs our attention to that problem by highlighting its editors's unstated assumption that genius must be sought only among the less well-supported variants, or through conjectural emendation. That assumption, fundamental to Kane's sense of the usus scribendi, also derives from the well-established editorial principle of lectio durior, which argues that the most distinctively authorial readings are the ones that scribes are most likely to change (KANE 1988, 127-28; Robinson 2004, 3.2). But the issue at hand interrogates the converse of that principle, an idea that cannot be made logically equivalent to it: granting the principles underlying lectio durior, it is still not necessarily true that the readings scribes consistently preserve intact are therefore indicative of a usus scribendi. Even a lection, a line, or a passage which they utterly fail to get wrong may still preserve the authorial text, perhaps even when the author's genius is in full bloom. That principle, obvious enough when stated plainly, is what the eclectic editors of III, 838 have lost sight of.

A quick look at lines that have for generations been recognized as embodying some aspect of Chaucer's genius - lines that we all agree no one else is likely to have written - confirms this point. To avoid cherrypicking my own evidence, I asked members of the Chaucer Listserve to nominate from the most-easily collatable texts the lines that best embodied Chaucer's genius as they understood it (FARRELL 2014), and they identified the six short passages totalling eleven lines whose textual history I summarize here. Most of the nominated lines were copied correctly by a substantial majority of scribes. The small number of trivial errors in the scribal record for the following lines does nothing to obscure the poet's brilliance.

But sooth to seyn, he was somdeel squaymous

Of fartyng, and of speche daungerous. (I, 3337-38)

"This wol I yeve thee, if thou me kisse."

This Nicholas was risen for to pisse. (I, 3797-98) 
Thow shalt be dreynt; my tale is at an ende.

$(\text { VII, 3082) })^{12}$

There is a perhaps predictably wider range of variation in the longest nominated passage:

This storie is also trewe, I undertake,

As is the book of Launcelot de Lake,

That wommen holde in ful greet reverence.

(VII, 3211-13)

Seventeen scribes wrote "as" for "also" in 3211, ten referred to "Launcelot the Lake", and a majority wrote past tense "helde" in 3213 (NUN'S PRIEST 2006, lines 391-93 ). A similar degree of scribalism appears when the Wife's restates the rationale for creating the organs of generation, "That is to seye, for office and for ese / of engendrure, ther we nat God displese" (III, 12728): minority "This" for "That", a few scattered "dar" displacing "ther", and various permutations (still a minority) of "engendrynge" for "engendrure" (Wife of Bath 1996, line 127-28). Pertelote's advice to "Pekke hem up right as they growe and ete hem yn" (VII, 2967) provoked the greatest variation: 22 witnesses have "Pyke" as the first word, and another six read "Plucke" In those verbs, much less specifically meaningful as suggestions to a rooster (especially "plucke"!), we can recognize a clear movement away from the usus poetandi and towards the usus scribendi. But even so, the most common reading of the line is the correct one, even if it occurs in only onethird of all witnesses (NUN's PRIEST 2006, line 147). In confirmation, Donaldson and Mann print the most common scribal form of all of these passages without emendation and with only minor spelling variation. ${ }^{13}$

Certainly, then, scribes are capable of error when Chaucer is at the peak of his powers, but this evidence does little to suggest that we should expect Chaucer's genius to be erased in the scribal record in any thoroughgoing way: each of the eleven lines I studied was reproduced exactly in at least five of nine well-known, usually early, good witnesses to the Tales, and eight

12. I, 3337-38 is reproduced correctly in 45 and 48 (respectively) of the 57 witnesses containing them; the most substantive variants narrow the grammatical ambiguity of the second line. Scribes copied a fully Chaucerian version of I, 3797-98 in 38 and 35, respectively, of 54 witnesses (MILLER's TALE 2004, lines 151-52 and 609-10, respectively). 44 of 54 witnesses quote Chauntecleer's line as cited (Nun's PRIEst 2006, line 262).

13. See Donaldson 1975, 112, 127, 195, 499, 502, and 506, and Mann 2005, 123, $139,215,604,608$, and 612 . 
of them appear without error in at least seven of that group. None of us is likely to be surprised that both Hengwrt and Ellesmere got all eleven right, or that Christ Church had only one error (writing "my tale is at ende" in VII, 3082). ${ }^{14}$ The assumption that Chaucer's scribes en masse are likely to get his most characteristic touches wrong - is wrong.

The burden of that evidence requires us to acknowledge that any editor considering rejection of a reading well-attested in the textual tradition of the Canterbury Tales should first at least consider the perhaps unexpected form of authorial genius it may evidence. Is it beyond imagination that the Summoner would tell the Friar to "amble or trotte or pees or go sit doun" fully expecting that his pilgrim audience would notice the oddity of his diction - and then grin at the obvious self-bowdlerization of his comment? Or, if that approach to textual issues smells too much of now-discredited "roadside drama" theories, is it beyond imagination that Chaucer would write "amble or trotte or pees or go sit doun" in the full expectation that his audience would pause over the oddity of the diction and then grin at the obvious authorial self-bowdlerization of the comment? After all, Donaldson himself seems to have gone through more or less that thought-process in coming to his understanding of the line. Perhaps Chaucer's audience would laugh the more because they understood the vagaries of textual dissemination, or because they knew that Chaucer knew and worried about the vagaries of textual dissemination. That is, we might imagine that the poet allowed to the Summoner a deliberate and fairly transparent euphemism, one that would irresistibly suggest the cruder comment his allotted speech elides. Some readers may consider unlikely, a bit too postmodern, the suggestion that Chaucer deliberately composed this line in a form that might encourage later readers to read-and later scribes to write - the lection "pisse". Perhaps it is as postmodern as the idea of having a character in one of the Canterbury Tales invoke the teller of a different tale as an authority (V, 1685-87), or having one of the poet's fictional pilgrims peer at Chaucer with the guileless question, "What man artow?" (VII, 1885).

14. My list of "good" witnesses comprises eight manuscripts - London, British Library, Additional MS 35286; Oxford, Christ Church, MS 152; Oxford, Corpus Christi College, MS 198; Cambridge University Library, MS Dd.4.24; San Marino, California, Huntington Library, El 26 C 9 ("Ellesmere"); Cambridge University Library, MS Gg.4.27; London, British Library, Harley MS 7334; and Aberystwyth, National Library of Wales, Peniarth 392 D ("Hengwrt") — and Caxton's second edition, revised from the first by collation with an excellent and probably early manuscript, now lost. 
In sum, the genie of authorial genius, once released, cannot be put back in the lamp. Eclectic editors have shown us the marvels that can be accomplished once we possess its power. Especially when the quality of the poem is imperfectly preserved in a textual tradition of (at best) middling authority - as is certainly the case in Piers A and B - we cannot be satisfied with any less powerful editorial tools. But let us, like Pearsall, at least learn the dangers of such irresistible power; let us seek to keep at arm's length the genie whose granting of wishes has always led to some results we claim not to have wanted.

\section{Works Cited}

Adams, Robert, et al., eds. 2000. The Piers Plowman Electronic Archive, Vol. 1: Corpus Christi College, Oxford MS 201 (F). Ann Arbor: University of Michigan Press.

Barney, Peter. 1993. "Line-Number Index to the Athlone Edition of Piers Plowman". Yearbook of Langland Studies 7: 97-114.

Boenig, Robert, and Andrew Tay lor, eds. 2012. The Canterbury Tales. 2nd ed. Peterborough, Ont.: Broadview Press.

Bowers, John M., ed. 1992, The Canterbury Tales: Fifteenth-Century Continuations and Additions. Kalamazoo, Mich.: Medieval Institute Publications.

Donaldson, E. Talbot. 1966. "The Psychology of Editors of Middle English Texts". Reprtd. Speaking of Chaucer. 102-18. New York: Norton (1970).

— New York: Ronald Press.

1976. "Some Readings in the Canterbury Tales". In Medieval Studies in Honor of Lillian Herlands Hornstein. Edited by Jess B. Bessinger, Jr. and Robert R. Raymo, 99-110. New York: New York University Press.

Edwards, A. S. G. 2010. "Manly and Rickert and the Failure of Method". Studies in the Age of Chaucer 32: 337-44.

FARrell, Thomas J. 2014. "End of semester fun”. CHAUCER@LISTSERV.UIC.EDU. 3 December.

Foucault, Michel. 1984. "What is an Author?" 1969; Joshué Harari, trans., 1979. Reprtd. in Paul Rabinow, ed., 101-18. The Foucault Reader. New York: Pantheon Books.

Gower, John. 2006. Confessio Amantis. Russell Peck, ed. 3 vols; vol 1. 2nd ed. Kalamazoo, Mich.: Medieval Institute Publications.

Hanna, Ralph III. 1997. “(The) Editing (of) the Ellesmere Chaucer”. In The Ellesmere Chaucer: Essays in Interpretation. Edited by Martin Stevens and Daniel WoodwARD, 225-43. San Marino, CA \& Tokyo: Huntington Library \& Yushodo Co., Ltd. 
2010. "George Kane and the Invention of Textual Thought: Retrospect and Prospect". Yearbook of Langland Studies 24: 1-20.

2014. "The Versions and Revisions of Piers Plowman". In The Cambridge Companion to Piers Plowman. Edited by Andrew Cole and Andrew Galloway, 33-49. Cambridge: Cambridge University Press.

Hudson, Anne. 1977. "Middle English”. In Editing Medieval Texts: English French, and Latin Written in England. Edited by A. G. Rigg, 34-57. New York: Garland.

KAnE, George. 1966. "Conjectural Emendation”. In Chaucer and Langland: Historical and Textual Approaches (London: Athlone, 1989). 150-61.

. 1986. '“Good' and 'Bad' Manuscripts: Texts and Critics”. Reprtd. in George Kane, Chaucer and Langland: Historical and Textual Approaches, 206-13. London: Athlone (1989).

- ed. 1988. Piers Plowman: The A Version. Will's Visions of Piers Plowman and Do-Well, Revised ed. London: Athlone Press.

- and E. Talbot Donaldson, eds. 1975. Piers Plowman: The B Version. Will's Visions of Piers Plowman, Do-Well, Do-Better and Do-Best. London: Athlone Press.

Kelly, Sean, James Simpson, et al. 2013. The Teaching of the Arts and Humanities at Harvard College: Mapping the Future. http://artsandhumanities.fas.harvard.edu /files/humanities/files/mapping_the_future_31_may_2013.pdf.

Mann, Jill, ed. 2005. The Canterbury Tales. London: Penguin.

The Miller's Tale on CD-ROM. 2004. Peter Robinson, ed. Leicester, UK: Scholarly Digital Editions.

The Nun's Priest's Tale on CD-ROM. 2006. Paul Thomas, ed. Birmingham, UK: Scholarly Digital Editions.

Patterson, Lee. 1987. Negotiating the Past: The Historical Understanding of Medieval Literature. Madison: University of Wisconsin Press.

Pearsall, Derek, ed. 1979. Piers Plowman by William Langland: an edition of the C-text. Berkeley: University of California Press.

1985. "Editing Medieval Texts: Some Developments and Some Problems". In Jerome J. McGann, ed., Textual Criticism and Literary Interpretation. Chicago: University of Chicago Press. 92-106.

- ed. 2008. William Langland, Piers Plowman: A New Annotated Edition of the C-Text. Exeter: University of Exeter Press.

- 2010. "Editing the C Text: The Athlone Press Edition of 1997". Yearbook of Langland Studies 24: 21-37.

Ramsey, Roy Vance. 2010. A Revised Edition of the Manly-Rickert Text of the Canterbury Tales. Lewiston, NY; Queenston, Ont.; Lampeter, Wales: Edwin Mellen Press.

The Riverside Chaucer. 1987. Larry Benson, gen. ed. Boston: Houghton Mifflin.

Robinson, Peter, ed. 1996. The Wife of Bath's Prologue on CD-ROM. Cambridge: Cambridge University Press.

1997. "A Stemmatic Analysis of the Fifteenth-Century Witnesses to The Wife of Bath's Prologue". The Canterbury Tales Project Occasional Papers 2: 69-132. 
2004. "The Witness Relations in Link 1 and the Miller's Tale”. The Miller's Tale on CD-ROM. Peter Robinson, ed. Leicester, UK: Scholarly Digital Editions.

2013. "The Concept of the Work in the Digital Age". Ecdotica 10: 13-41.

Russell, George and George Kane, eds. 1997. Piers Plowman: The C Version. Will's Visions of Piers Plowman, Do-Well, Do-Better and Do-Best. London: Athlone Press.

Salter, Elizabeth and Derek Pearsall, eds. 1967. Piers Plowman. Evanston: Northwestern University Press.

Schmidt, A. V. C., ed. 2011. Piers Plowman: A Parallel-Text Edition of the A, B, C and $Z$ Versions, 2 vols., Revised ed. Kalamazoo: Medieval Institute Publications.

Spisak, James, ed. 1983. Caxton's Malory: A New Edition of Sir Thomas Malory's Le Morte Darthur Based on the Pierpont Morgan Copy of William Caxton's Edition of 1485. Berkeley and Los Angeles: University of California Press.

Tanselle, G. Thomas. 1989. A Rationale of Textual Criticism. Philadelphia: University of Pennsylvania Press.

Vaugh an, Míceál, ed. 2011. Piers Plowman: The A Version. Baltimore: Johns Hopkins University Press.

Watson, Nicholas and Jacqueline Jenkins. 2006. The Writings of Julian of Norwich: A Vision Showed to a Devout Woman and A Revelation of Love. University Park: Pennsylvania State University Press.

The Wife of Bath's Prologue on CD-ROM. 1996. Peter Robinson, ed. Cambridge: Cambridge University Press. 